\title{
FEDERAL ESTATE AND GIFT TAXATION: AMENDED REGULATIONS CHANGE VALUATION FOR ESTATE AND GIFT TAXES
}

\author{
Changes in valuation regulations mean higher values and increased \\ taxes. The amendment itself and the concurrent T.I.R. absorb \\ much of the force of the changes.
}

$\mathrm{U}$ NDER CURRENT Internal Revenue Code provisions, both federal estate and gift taxes are imposed on the value of the property subject to the tax. ${ }^{1}$ Thus, valuative standards and techniques become critical, valuation being the "key factor in the imposition of estate tax and gift tax."2 Fair market value $e^{3}$ has long been the standard of valuation for the imposition of these taxes, ${ }^{4}$ with negotiation and compromise commonplace in agent-taxpayer dealings, although pursuant to no statutory authorization..$^{5}$ The delimitation of the relevant market to be used as a frame of reference in valuation has never been precise, however. Prior to 1965, the Treasury Regula-

\footnotetext{
${ }^{1}$ INT. REv. CODE OF 1954, $\S \S 2031 \mathrm{a}, 2512 \mathrm{a}$.

For the estate tax this value is determined as of the date of the decedent's death, INT. REv, CODE of 1954, $\$ 2031$, or on an alternate date which is generally one year aftcr the decedent's death; sce INT. REv. CODE of 1954, § 2032. For the gift tax this value is determined as of the date of the gift. INT. REv. CODE of $1954, \S 2512$.

21 Mertens, Federal Gift and Estate Taxation, § 6.01, at 336 (1959).

'The regulations define fair market value as follows: "the price at which the property would change hands between a willing buyer and a willing seller, neither being under any compulsion to buy or to sell and both having reasonable knowledge of relevant facts. ... [ [N]ot to be detcrmined by a forced sale price. . . All relevant facts and elements of value as of the applicable valuation date shall be considered in every case." Treas. Reg. $\S 20.2031-1$ (h) (1958), as amended, T.D. 6826, 1965 INT. Rev. BuLL. No. 27, at 13 (estate tax). The gift tax regulation is substantially the same. Treas. Reg. $\S 25.2512-1$ (1958), as amended, T.D. 6826, 1965 INT. Rev. Bulr. No. 27, at 15. The date on which fair market value is to be determined is specified in $\S \S 2031,2032,2512$ of the Internal Revenue Code of 1954. See note 1 supra.

This is the same willing buyer-willing seller approach to fair market value that the courts have adopted. Estate of Fitts v. Commissioner, 237 F.2d 729, 731 (8th Gir. 1956); Robertson v. Routzahn, 75 F.2d 537, 539 (6th Cir. 1935). In addition, local tax assessments are not considered necessarily reliable in determining fair market value. Estate of Walter Lippincott, 27 B.T.A. 735, 740 (1933), rev'd on other grounds, 72 F.2d 788 (3d Cir. 1934). Treas. Reg. $\$ \$ 20.2031,20.2512$ (1964). See 2 Beveridge, Federal Estate Taxatton $\$ 19.01$, at 362 (1956). For a general discussion of the fair market value concept see Gordon, What is Fair Market Value?, 8 TAx. L. REv. 35 (1952).

- See 1 MERTENs, op. cit. supra note 2, § 6.02 nn.3 \& 5.

${ }^{5}$ Although negotiation and compromise are common methods of determining value, courts seldom acknowledge the ad hoc nature of the process. See LowndEs
} 
tions did not specify the type of market setting which was to be used as a basis for determining fair market value. In June 1965, however, these regulations were amended and now specify that the fair market value of an item is to be determined by its hypothetical sale price in a market where such items are "most commonly sold to the public."6 Thus, a retail and not a wholesale transaction has been adopted as the relevant market test for items "generally obtained by the public in the retail market."7 An illustration provided by the regulations demonstrates the distinction between this new retail market test and the wholesale context: the value of a used automobile will be the estimated price which the public would pay to a used automobile dealer to obtain a similar automobile rather than the price that a dealer would pay a private owner for such an automobile. ${ }^{8}$

The retail market test, with its resultant higher valuation of property, is consistent with the two chiefly articulated justifications for estate and gift taxation: production of revenue and reduction

\& Kramer, Federal Estate AND GIFT TAXEs \$ 18.16 (2d ed. 1962); Powell, Estate Valuation-The Internal Revenue Service Standpoint, 22 Omо ST. L.J. 249 (1961). The importance of these negotiations is emphasized by the presumption favoring the ultimate valuation set by the Commissioner. "The Commissioner having determined a valuation for the assessment of the estate tax, the taxpayer must adduce legal, admissible, and convincing evidence of error to sustain his appeal." Estate of Lucy H. Sturgess, 2 B.T.A. 69, 70-71 (1925).

For a study of judicial approach in cases involving contested valuation figures see Bosland, Tax Valuation by Compromise, 19 TAx L. REv. 77 (1963). In one case a dissenting judge pointed out the difficulty in finding a basis in legal rule for determinations of valuation by the Tax Court when he noted that the court's valuation figure of $\$ 375$ was the arithmetic mean of the $\$ 150$ figure proposed by the taxpayer and the $\$ 600$ figure set by the Commissioner. Estate of Fitts v. Commissioner, 237 F.2d 729, 734 (8th Cir. 1956) (dissenting opinion).

"Nor is the fair market value of an item of property to be determined by the sale price of the item in a market other than that in which such item is most commonly sold to the public . . . Treas. Reg. $\$ 20.2031-1(\mathrm{~b})$ (1958), as amended, T.D. 6826, 1965 INT. REv. BuLl. No. 27, at 13 (estate tax). The amended gift tax regulations now contain a similar provision. Treas. Reg. $\S 25.2512-1$ (1958), as amended, T.D. 6826, 1965 INT. REv. BuLl. No. 27, at 15.

7 Treas. Reg. $\S \S 20.2031 .1$ (b), 25.2512-1 (1958), as amended, T.D. 6826, 1965 INT. Rev. Bull. No. 27, at 13 and 15 .

In the past courts have suggested that even though the class of possible buyers at retail is limited and small, the possibility of such a sale cannot be discounted. Thus, in a gift tax case involving the valuation of expensive diamonds, the court said: "While it may be true that the speediest and most convenient way to dispose of a large diamond is by sale to an established dealer, wholesale or retail, the possibility of a more favorable private sale cannot be entirely eliminated." Pubhicker v. Commissioner, 206 F.2d 250, 253 (3d Cir. 1953), cert. denied, 346 U.S. 924 (1954).

${ }^{8}$ Treas. Reg. $\$ \S 20.2031-1$ (b), 25.2512-1 (1958), as amended, T.D, 6826, 1965 INT, REv. BuLl. No. 27, at 13,15 . 
of excessive accumulations of wealth. ${ }^{9}$ However, while rigid application of the retail test would clearly further these ends, the Commissioner deemed it desirable in certain situations to partially ameliorate the impact of the amendment with respect to estate taxation..$^{10}$ Thus, where the estate sells an item of estate property to a "dealer"11 for less than fair market value, ${ }^{12}$ the amount by which the fair market value of the item exceeds the actual sale price to the dealer is classified as an administrative expense and may be deducted

' See Gleason \& Oms, Inheritance Taxation and the federal Estate and Gift Taxes 9 (4th ed. 1925); Paul, Taxation for Prosperity 214-15 (1947); Eisenstein, The Rise and Decline of the Estate Tax, 11 TAx L. REv. 223, 238 (1956).

For a general history of federal estate and gift taxation see BLAKEMORE \&: BANCroft, Inhertance Tax LAw 15-16 (1912); Green, Theory and Practice of Modern Taxation 165 (1933); Hughes, The Federal Death Tax $\$ \S 1,231$ (1938); 2 Paul, Federal Estate aNd Gift Taxation \$§ 15.01-15.04 (1942); Eisenstein, supra at 224-38.

Questions concerning fairness in the application of the federal estate and gift taxes are often answered by the contention that such taxes are officially levies on the privilege of transferring property. Sec New York Trust Co. v. Eisner, 256 U.S. 345, 348-50 (1921); Knowlton v. Moore, 178 U.S. 41, 56-61 (1900); Iglehart v. Commissioner, 77 F.2d 704, 712 (5th Cir. 1935). "These federal taxes are im. posed upon the transmission of property rather than upon its receipt, which sup. ports an approach reflecting cost rather than immediate value to the donce." STEphens \& MARR, The Federal Estate and Gift TaXes 337 (1959). However, it has been suggested that the truly fair method of valuation for such taxes would be based on the value of the property to the recipient. "[T] he burden of the tax falls upon the beneficiaries, even if the tax is paid by the executors out of the estate as such. 'Value of the property' should therefore be interpreted to mean (or to be the approximate index of) that value which is significant to the beneficiaries-in short, a special form of the concept of 'value to the owner.' Clearly, the worth of the estate to the decedent is of no consequence here. But equally truly, its market value, in the strict sense of the price at which it might be sold to any outside party, is irrelevant save as a possible measure of the value of the property to those who inherit it," 2 Bonbright, ThE VAluation of Property 694-95 (1937).

${ }^{10}$ Treas. Reg. $\S 20.2053$ (d) (2) (1958), as amended, T.D. 6826, 1965 INT. REv. BulL. No. 27, at 14. A similar provision was not included in the gift tax regu. lations since no provision is made for deductions of expenses for that tax.

11 The term dealer is not defined in the estate tax regulation. Reference is made to a dealer in the automobile example given to illustrate the retail market test. See text accompanying note 8 supra. This may suggest the popular or common usage of the term, denoting someone one step removed from the public in the market structure. However, it is also possible that it has been used in a technical sense. If "dealer" is to be regarded as a word of art, $\$ \$ 1.453-1$ (a) (dealers in personal property under the installment method), 1.471 .5 (dealers in securities) of the regulations may be of assistance in divining its proper interpretation. Treas. Reg. $\S 1.453-1$ (a) (1958), as amended, T.D. 6682, 1963-2 CuM. Bull. 197; Treas. Reg. $\S 1.471-5(1958)$. Since no definition of a dealer was proffered by the reginlations and given the contextual use of the term in the automobile example, it seems likely that the term has been used in its common usage; that is, someone one step removed from the public in the market structure, such as the automobile dealer.

${ }^{12}$ Fair market value is determined by $\$ \S 20.2031-1$ to -9 of the estate tax 
from the gross estate. ${ }^{13}$ Such a sale must be both bona fide and "necessary in order to pay the decedent's debts, expenses of administration or taxes, to preserve the estate, or to effect distribution."14

A further modification of the rigors of the retail market test was provided by Technical Information Release 737, issued the day following the release of the amended regulations. ${ }^{15}$ It prescribed two situations where the sale price of an item disposed of by an estate will be presumed to be its fair market value.18 Thus, under section 3 of the release the price obtained in a bona fide ${ }^{17}$ sale of tangible personalty effected either at a public auction or initiated through the use of classified newspaper advertisements will be presumed to be the relevant retail sales price for valuation purposes..$^{18}$ However, this presumption will be deemed applicable only where there has been no "substantial change" in market conditions and when the sale date "reasonably follows" the controlling valuation date. $^{10}$

regulation on either the date of the sale or the appropriate valuation date (as determined by $\S \S 20.2031-1$ or $20.2032-1$ ) whichever date results in the lower valuation. Treas. Reg. $\S 20.2053-3$ (d) (2) (1958), as amended, T.D. 6826, 1965 INT. REv. BuLl. No. 27, at 14 .

${ }^{13}$ The necessary sale expense deduction, at first glance simply a mitigation of fair market value, is in substance of much greater siguificance since it creates a new estate tax deduction. A necessary sale to a dealer may result in a paper loss when the proceeds therefrom are compared to the fair market value of the items sold. This hypothetical loss, however, is categorized as an administrative expense, which in turn is allowed as a deduction. It is possible that this intricacy is required because of the exclusive definition given to a deductible loss under the estate tax provisions of the code. Losses deductible for estate tax purposes are enumerated, INT. REv. CODE oF 1954, $\S 2054$, and selling losses are not mentioned.

14 Treas. Reg. $\$ 20.2053-3$ (d) (2) (1958), as amended, T.D. 6826, 1965 INT. Rev. BuLl. No. 27, at 14. (Emphasis added.)

16 T.I.R. 737, § 3, Rev. Proc. 65-19, 1965 INT. REv. BuLl. No. 27, at 19.

${ }^{16}$ Ibid.

${ }^{17}$ For the criteria for a bona fide sale see notes 50-52 infra and accompanying text.

18 T.I.R. 737, § 3, Rev. Proc. 65-19, 1965 INT. Rev. Bull. No. 27, at 19.

10 Ibid. The terms substantial change and reasonably follows are not clarified in the regulations. Substantial change suggests a test based on particular circum. stances in the market for the item under consideration. Reasonably follows is likewise probably to be determined on an individual basis. The probable purpose of these terms is to prevent the creation of a third possible valuation date for tangible personalty. Without such a requirement an executor might be able to obtain favorable valuation by taking advantage of changed market conditions for tangible personalty while still being able to select his overall valuation date on the basis of other considerations. For a survey of the alternate valuation dates which an executor may select as controlling, see note I supra. The "substantial change" requirement would seem to preclude this option when there is a sudden shift in market conditions, while the "reasonably follows" requirement will take care of situations where there is a gradual and constant change. 
Given the pivotal importance of valuation, these alterations of the relevant market concept are highly significant..20 The language of the amended regulations is imprecise in several particulars, ${ }^{21}$ however, and a resolution of future problems inherent in the regulation's ambiguities may be facilitated by viewing them in light of traditional valuation methodology. Two approaches have been previously utilized in resolving specific valuation problems. Reference may be made to valuation techniques employed in other legal contexts, ${ }^{22}$ or the inquiry may be restricted to the specific area of valuation being examined.23 Both approaches are valuable and the practitioner may find it especially helpful to augment his specialized research with forays into related areas.

A ready analogy to estate and gift valuation is afforded by the income tax laws, where a determination of fair market value is likewise required in many situations. For example, the Internal Revenue Code requires that the value of prizes and awards received by the taxpayer be included in taxable income. ${ }^{24}$ Fair market value for non-cash items so received is determined by ascertaining the amount the taxpayer would have received had he sold the item. ${ }^{25}$ This approach has occasionally been referred to as the "money's worth" test. ${ }^{28}$ Similarly, the fair market value of a charitable

${ }^{20}$ The importance of regulations identifying the market encompassed within the term "fair market value" is emphasized by the general absence of case law dealing with the type of market to be considered. However, several cases have raised the point by implication where the money's worth test was rejected in favor of the replacement cost test. See Guggenheim v. Rasquin, 312 U.S. 254 (1941); Publicker v. Commissioner, 206 F.2d 250 (3d Cir. 1953), cert. denied, 346 U.S. 924 (1954); Estate of Frank Miller Gould, 14 T.C. 414 (1950); notes 24, 27 infra.

${ }^{21}$ See text accompanying notes $42-55$ infra.

22 "An attorney faced with a question of valuation under the federal estate or gift taxes should not hesitate to include in his research the federal income and excess profits tax cases and rulings on valuation, and in addition state taxation cases, and rate regulation, eminent domain and damage cases, state or federal, involving valuation problems similar to his." Lowndes \& KRAMER, op. cit. supra note 5, $\$ 18.1$, at 418 .

${ }_{23}$ "[I]n American law at least, both the concepts of value and the technique of its proof are decidedly influenced by the specific purpose for which the valuation is made." 1 BONBRIGHT, op. cit. supra note 9, at 4-5. Therefore, the result has been that there are "fundamental differences in substantive law-in the very meaning of the phrase "value of the property' as a legal objective." Id. at 5 .

24 INT. REv. CODE OF 1954, \$ 74.

${ }^{25}$ Lawrence W. McCoy, 38 T.C. 841 (1962), acq., 1963-1 Cum. Bulc. 4 (value of new car won in sales contest). But see Reginald Turner, 23 P-H Tax Ct. Mem. 464 (1954) (steamship tickets won in radio contest were given compromise valuation). In neither case was the question of market specifically raised.

${ }^{20}$ The "money's worth" test has been articulated as "what-you-could-have-got-for- 
contribution, deductible by the donor under section 170 of the code, ${ }^{27}$ has been determined as the price that the article brought when subsequently sold. ${ }^{28}$ In both situations, however, the conflicting valuation techniques were the money's worth or seller's test and the replacement cost or buyer's test, rather than the type of market under consideration.

In the specific area of federal estate and gift taxation, the trend in valuation has been toward the replacement cost approach, which is occasionally referred to as the "buyer's test." In the first important valuation cases to consider this approach, the courts accepted the contention of the Commissioner that insurance policies should be valued at their replacement cost rather than at their cash surrender value as proposed by the taxpayer. ${ }^{29}$ The Commissioner's view that the federal excise tax should be included when valuing articles upon which such tax is imposed has also been judicially accepted. ${ }^{30}$ A more recent indication of the trend toward replacement cost came in 1963 when the Treasury specified that the value of shares in an open-end mutual fund investment company will be public offering price rather than redemptive value. ${ }^{31}$ Indeed, the

it-in-money-if-you-had-sold-it." Andrews v. Commissioner, 135 F.2d 314, 317 (2d Gir.) (Frank, J.), cert. denied, 320 U.S. 748 (1943).

27 INT. REv. CODE OF 1954, § 170.

2s The best evidence of the fair market value of the goods was the price they brought when sold shortly after being donated. Philip Kaplan, P-H T.C. REP. Dec. If 43.53, at 487 (Feb. 17, 1965), acq., 1965 INr. Rev. BuLl. No. 34, at 6. Contra, Daniel S. McGuire, P-H T.C. REP. Dec. I 44.75 (Sept. 13, 1965) (valuation set between the amount claimed by taxpayer and that allowed by the Commissioner). In neither of these cases was there an inquiry into the nature of the relevant market. Rather, the issue was whether the test to be applied was replacement cost, money's worth or some other monetary standard.

${ }^{20}$ Guggenheim v. Rasquin, 312 U.S. 254 (1941); Powers v. Commissioner, 312 U.S. 259 (1941); United States v. Ryerson, 312 U.S. 260 (1941).

The replacement cost approach has also been adopted for annuity contracts. "It is now settled that for estate tax purposes a valuation of annuity contracts based on replacement cost at the date of death is proper and reasonable." Estate of John L. Walker, 8 T.C. 1107, 1111 (1947). Cf. Farha Schayek, 33 T.C. 629, 634-35 (1960) (value of gift in trust is amount passing from donor, not amount received by donee); E.T. 7, XIV-1 Cum. BurL. 382 (1935) (value of gift in trust includes trustee's commission since value is the cost to the donor).

${ }^{30}$ Publicker v. Commissioner, 206 F.2d 250, 256-57 (3d Cir. 1953), cert. denied, 346 U.S. 924 (1954); Duke v. Commissioner, 200 F.2d 82 (2d Cir. 1952), cert. denied, 345 U.S. 906 (1953). See 7 VAND. L. REv. 292 (1954). The Tax Court has articulated the rationale underlying the replacement cost approach by saying in part: "If the decedent had given his wife the money to buy this ring ...." Estate of Frank Miller Gould, 14 T.C. 414, 417 (1950).

The Commissioner's position was stated in Rev. Rul. 55-71, 1955-1 Cum. BuLl. 110. Present regulations continue this practice. Treas. Reg. $\S 25.2512-7$ (1958).

31 Treas. Reg. $\S \S 20.2031-8$ (b), 25.2512-6(b) (1958), as amended, T.D. 6680, 1963-2 Cum. Bull. 417, 419-20. 
amended valuation regulations are in part manifestations of the Commissioner's favorable disposition toward replacement cost. ${ }^{\mathbf{3 2}}$

The sole departure from the trend toward replacement cost valuation in the estate and gift tax field is the blockage principle ${ }^{33}$ currently recognized by the Internal Revenue Service. That principle is employed in situations where the amount of the particular security holding which is to be valued may be so large that an actual sale in bulk of the securities would depress the market and thus cause realization of a lower price per share than would otherwise result. The blockage approach takes cognizance of this effect and permits valuation at a lower hypothetical block sale price rather than the market price of a single share. ${ }^{34}$ Application of the blockage principle, then, results in utilization of the lower money's worth test rather than the higher replacement cost standard.35 In 1958, after twenty years of resistance to this approach, ${ }^{36}$ the Commissioner

The replacement cost approach is also used for valuation of stocks and bonds, with their value determined by the selling price in the market. Treas. Reg. $\$ \S$ 20.2031-2(b), 25.2512-2(b) (1958). See Marks, Little-Publicized Valuation Regs Mean Higher Estate and Gift Taxes, 22 J. TAxATION 286 (1965).

${ }^{32}$ See text accompanying notes $46-48$ infra.

${ }^{33}$ See Lowndes \& KRAMER, op. cit. supra note 5, § 18.26; Riecker, Blockage in Federal Estate and Gift Tax Valuation, Mich. S.B.J., Aug. 1963, p. 24. For an excellent summary of the positions of both sides of the blockage question see Helvering v. Maytag, 125 F.2d 55, 62 (8th Cir.), cert. denied, 316 U.S. 689 (1942). The Treasury contended that businesses do not use blockage in valuing their portfolios, that blockage will frustrate the intent of Congress to levy a graduated tax, and that without a sale there is no effect on the market at all. On the other hand, the taxpayer argued that the size of the holding should be considered if the block of securities could not be sold in a reasonable time without effecting the price. Ibid.

3s "If the executor can show that the block of stock to be valued is so large in relation to the actual sales on the existing market that it could not be liquidated in a reasonable time without depressing the market, the price at which the block could be sold as such outside the usual market, as through an underwriter, may be a more accurate indication of value than market quotations." Treas. Reg. $\$$ 20.2031-2 (c) (1958). The gift tax regulations contain a similar provision. Treas. Reg. $\$ 25.2512-2$ (e) (1958).

${ }^{35}$ In a recent case involving blockage, the value of the securities in question was determined to be $\$ 84$ a share rather than the market value of $\$ 87$ a share as con. tended by the Commissioner.

"The executors have shown that the block of 1,440 shares was of a size that would have depressed the price of the stock on the market in the light of the volume of trading occurring at the time of decedent's death and that the amount by which the price would have been depressed reasonably approximated the cost of selling the stock on a secondary basis. I find, consequently, that the fair market value of the stock for estate tax purposes in this case was $\$ 84$ a share." Estate of Bartol v. McGinnis, 185 F. Supp. 659, 662 (E.D. Pa. 1960).

${ }^{2} \mathrm{~A}$ brief summary of the Commissioner's lack of success in opposing the blockage principle is found in Helvering v. Maytag, 125 F.2d 55, 63 (8th Cir.), cert. denied, 316 U.S. 689 (1942). The court comments on the "persistence of the Commissioner" but states that "the decisions are unanimously against him." 125 F.2d at 63. 
accepted the principle and presently will permit use of the blockage technique when its applicability is substantiated by the taxpayer. ${ }^{37}$

While valuation methods in both income taxation and generic estate and gift taxation areas may in a given case afford a viable analogy for problems arising under the retail market test, wholesale borrowing of these concepts is improper. For example, while a sale to a dealer by an estate is not considered determinative in establishing fair market value under the amended estate tax regulations, ${ }^{38}$ the actual price received from a sale to a dealer has been utilized in valuing property for the charitable contribution deduction. ${ }^{39}$ This divergence is explicable by the differing policy considerations in each situation, ${ }^{40}$ but emphasizes the inherent difficulty of using the same language in different tax regulations to achieve dissimilar objectives. ${ }^{41}$

While the amended regulations do clarify the Commissioner's position on valuation to the extent that they place determination of fair market value in a retail market setting, they have also created several interpretative problems. One complication is suggested by the statement in the amendment to the effect that consideration will be given to the geographic location of an item in determining its fair market value. ${ }^{42}$ The degree to which market value has thus

37 Rev. Rul. 59-60, 1959-1 Cum. BuLl. 237.

${ }^{38}$ While a sale to a dealer is not determinative of fair market value, a "necessary" sale to a dealer qualifies for the necessary sale expense deduction. Treas. Reg. $\S$ 20.2053-3 (d) (2) (1958), as amended, T.D. 6826, 1965 INT. REv. BuLL. No. 27, at I4.

${ }^{30}$ See note 28 supra and accompanying text.

to For example, the objectives of the estate tax are to reduce the accumulation of wealth and provide a source of revenue. See note 9 supra and accompanying text. A higher valuation will best accomplish this purpose. On the other hand, the income $\operatorname{tax}$ is imposed on the amount "realized" by the taxpayer. Eisner v. Macomber, 252 U.S. 189,211 (1920).

Moreover, policy objectives within the income tax field differ in some instances. For example, since the income tax is a means of producing revenue, determination of the amount of taxable income realized might be approached differently than valuation of a deduction. Thus, the seemingly consistent application of the money's worth test for the valuation of prizes and for charitable contributions may demonstrate inconsistent policy decisions. In one instance the benefit of the lower valnation goes to the taxpayer, in the other to the government. Compare Reginald Turner, $23 \mathrm{P}-\mathrm{H}$ Tax Ct. Mem. 464 (1954), with Philip Kaplan, P-H T.C. REP. DEc. I 43.53 (Feb. I7, 1965), acq., 1965 INT. Rev. BulL. No. 34, at 6.

11 A distinguished federal court of appeals justice has observed: "At the bottom of respondents' contention is this implied assumption: The same transaction cannot be a completed gift for one purpose and an incomplete gift for another. Of course, that is not true, as the cases above cited make clear. Perhaps to assuage the feelings and aid the understanding of affected taxpayers, Congress might use different symbols to describe the taxable conduct in the several statutes, calling it a 'gift' in the gift tax law, a 'gaft' in the income tax law, and a 'geft' in the estate tax law." Commissioner v. Estate of Beck, 129 F.2d 243, 246 (2d Cir. 1942) (Frank, J.).

${ }^{12}$ Treas. Reg. $\$ \S 20.2031-\mathrm{I}$ (b), 25.2512-I (1958), as amended, T.D. 6826, 1965 INT. 
been localized is not specified and indeed may vary areally for each type of article under consideration. ${ }^{43}$ Consideration of location on an article-by-article basis appears to be a more realistic approach to the problem than an attempt to outline a general local market for all items. A test might be suggested which defines the relevant geographic area as that within which a reasonable seller would operate in an attempt to dispose of the article in the retail market.44 Utilizing this test, considerations of location might require lowering the valuation of an item by an amount equal to the hypothetical cost of shipping it to an area of greater demand where a higher retail price might be realized, if this would be the most efficacious tack a reasonable seller would take to maximize his net return on the sale. This approach would seem especially appropriate when the value of an item in a strictly local market is extremely low due to an unusually light demand for items of this type which is peculiar to the immediate locale. 45

The dominant theme of the amendment is the application of the replacement cost test to those items generally obtained by the public in the retail market. ${ }^{46}$ Items commonly acquired in other channels will apparently be valued by a different method which as yet remains unstated. ${ }^{47}$ Yet another ambiguity is inherent in the requirements of the subsequently released T.I.R., which provided that an actual sale price be presumed to be the fair market value only where the

Rev. BuLL. No. 27, at 13-15. Commentators prior to the amended regulations deemed it desirable to take some account of the effect of location on valuation and some writers suggest that locale has often been an ad hoc consideration. "The effect of location on valuation has not, however, been clearly articulated by legal authorities due perhaps to the fact that it is usually assumed without much specific discussion. Ordinarily it would appear that property should be valued according to its value at the place where it is located unless it is of a type whose value is not affected by local conditions." Lowndes \& KRAMER, op. cit. supra note $5, \S 18.8$, at 437-38.

${ }^{3}$ For example, the market for some widely held securitics is at least national in scope, while that for most realty will probably be more local in nature.

1t The standard for this test would be the behavior of a reasonable seller intent on maximizing his net return from the sale of the property in question.

s5 Demand may be very slight for arctic clothing in Florida or tobacco cultivation equipment in Wyoming.

${ }^{4}$ See note 6 supra.

47 A possible alternative method is valuation based on the cash surrender value of the article, also known as the money's worth or the seller's test. See notes 25-26 supra and accompanying text. Another alternative is valuation in accordance with the special personal value to the recipient. See 2 BONBRIGHT, op. cit. supra note 9, at 694 95. The Commissioner may be willing to retain the pre-amendment compromise approach to valuation, see note $\mathbf{5}$ supra, since the method for determining the relevant market for items not generally obtained in a retail market might be difficult to articulate. 
item sold is both tangible personalty generally obtained at retail and is "frequently" sold at public auction or through classified newspaper advertisement. ${ }^{48}$ The market standards established by these provisions are, at best, vague guidelines for the taxpayer. Precise delineations as to how often articles from a class of items must be disposed of to be considered "frequently" or "generally" sold are left uncharted, ${ }^{49}$ and delimitation will probably vary with the differing characteristics of each type of property. Further, items "frequently" or "generally" sold in the prescribed manners in one part of the country may be marketed by divergent methods in another.

An additional consideration which poses interpretative problems is the proviso that a sale must be "bona fide" in order to qualify for the sale price presumption under the terms of the T.I.R.50 A sale to a family member or some other interested party ${ }^{51}$ at a small public auction, or a sale which occurs unreasonably soon after the publication of a classified advertisement may cast suspicion on the bona fides of the sale. A careful executor might avoid such anticipated objections by utilizing methods to publicize the auction which are commonly used in the area and by insuring that his advertisements were placed in appropriate newspapers for a reasonable time before conclusion of a sale. ${ }^{52}$

Finally, an interpretative problem is suggested by that provision of the amended regulations which allows an administrative expense

18 T.I.R. 737, \& 3, Rev. Proc. 65-19, 1965 INT. Rev. Buli. No. 27, at 19.

10 Ibid. The precise meaning of the words "generally" and "frequently" as used in the T.I.R. are not specified. However, it is obvious that they are not considered mutually exclusive terms given the language that items "generally available ... at retail establishments, frequently are obtained ... at a public auction or through sales which result from advertisements placed in the classified section of a newspaper." Ibid. (Emphasis added.) Whatever meaning may be drawn from the literal wording of the T.I.R. itself, its ultimate effect will be largely determined by the intent of the Commissioner in formulating it. The provision applies only to tangible personalty, perhaps because of the difficulty in distributing such property among general legatees and the likelihood that a sale will result. The generally and frequently requirements may be designed to further restrict the apphication of the provision, perhaps to personal effects, household furnishings and other such articles of personal use that may have little monetary value to a legatee.

${ }^{10}$ Ibid.

62 E.g., a business associate, Du Pont v. Commissioner, 118 F.2d 544 (3d Cir. 1941), cert. denied, 314 U.S. 623 (1941); relative, Schoenheit v. Commissioner, 14 B.T.A. 33 (1928), aff'd sub nom. Schoenheit v. Lucas, 44 F.2d 476 (4th Cir. 1930); friends, Young v. Commissioner, 6 B.T.A. 656 (1927); or a member of executor's family, McWilliams v. Commissioner, 331 U.S. 694 (1947); Shethar v. Commissioner, 28 T.C. 1222 (1957).

${ }^{02} \mathrm{It}$ is suggested that a reasonable seller test be adopted in this area also, see note 44 supra. Thus, if a reasonable seller would have made such a sale while bent on maximizing his return, it will be accepted as bona fide. 
deduction where there is a sale to a dealer which is deemed "necessary." ${ }_{33}$ The factual question of a sale's necessity may pose difficulties in several situations. For example, it is doubtful that a sale which is made to facilitate the distribution of estate property will qualify. ${ }^{54}$ The problem of securing sufficient funds to meet administrative expenses, debts and tax liability varies with the particular characteristics of each estate, and the degree of difficulty which an executor must show he has encountered in meeting these payments without selling estate property remains unspecified..$^{55}$

In addition to the interpretative problems, the amended regu* lations suggest certain tax avoidance devices heretofore unavailable to the taxpayer. For example, to mitigate the effect of the retail market approach an executor might first meet estate expenses by selling to a dealer those items of tangible personalty which are rarely sold at a public auction or through classified advertisements.to This would afford him a necessary sale deduction under some circumstances ${ }^{57}$ and thereafter he could sell remaining articles of tangible personalty at an auction or through classified advertisements and thus achieve the benefit of the presumption that the sale price obtained is the fair market value of an item. ${ }^{58}$ Whether such a gam-

${ }^{53}$ Treas. Reg. $\$ 20.2053$ (d) (2) (1958), as amended, T.D. 6826, 1965 1NT. REv. BuLL. No. 27 , at 14. This deduction permits avoidance of the harsh effects of the retail market standard under conditions where a sale is pragmatically necessary. The intricate procedure followed for the necessary sale deduction reaches basically the same result as does that outlined in T.I.R. 737 in that it treats the sale price as the presumed fair market value. See text accompanying notes 15.19 supra. This is not to say that the two approaches may in the necessary sale context reach the same result, because they operate under different circumstances. However, the procedures reach similar results. Assuming an article with fair market value of $\$ 100$ is sold for $\$ 80$, the resulting taxable amount included in the estate will be $\$ 80$ whether the value of the article is taken as $\$ 80$ or the value is taken to be $\$ 100$ and a deduction of $\$ 20$ is allowed. The income tax consequences would be quite different, however, if the executor should elect to take the deduction in the tax return for the income tax of the estate. INT. REv. CODE of 1954, § 642 (g).

"t The regulation requires a sale "necessary ... to effect distribution." Treas. Reg. $\S 20.2053-3$ (d) (2) (1958), as amended, T.D. 6826, 1965 INT. REv. BuLL. No. 27, at 14. (Emphasis added.) A sale which merely facilitates convenience of distribution would thus not appear to qualify, although an executor might attempt to establish the necessity for such a sale on other than financial grounds. Efforts to avoid contest of the will by placating legatees might be interposed as "necessary."

${ }^{56}$ In this case a suggested standard might hypothesize a reasonable executor attempting to meet the obligations of the estate. However, this reasonable executor would probably be precluded from using tax avoidance possibilities to influence his decisions.

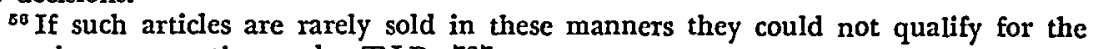
sale price presumption under T.I.R. 737.

${ }^{57}$ See text accompanying note 14 supra.

${ }^{68}$ In the gift tax field, valuation considerations may encourage a prospective 
bit will prove successful may turn on judicial willingness to determine "necessity" by examining only those circumstances which are manifest at the time of the sale-for-expenses. By taking an overview of the entire pattern of estate disposition, sales which are in substance convenient tax mitigation devices may be treated as such rather than as "necessary." "50

Under the regulations prior to these amendments, fair market value was in practical effect largely a product of negotiation and compromise. ${ }^{60}$ The amended regulations have done little to alter this practice since valuation problems have merely been placed in a retail market setting. Moreover, several new interpretative problems and tax avoidance methods are foreseeable under the amendments. Since the valuation process is one not readily adaptable to

donor to sell those articles not especially desired by the prospective donee, and then make the gift of the proceeds of the sale, unless income tax consequences to the donor dictate otherwise. In the case of tangible personalty he could then be sure that the taxable value of the gift would not be far above its worth to the donee.

The effect of the amended regulations is to discriminate by means of higher tax valuation against items of property specifically bequeathed or donated since the executor of a solvent estate will not have the option to sell such items to achieve the favorable presumption or expense deduction and the donee may sell the property for much less than the value put upon it for the gift tax.

${ }^{\circ 0}$ In granting relief to what may be considered the harsh result of replacement cost valuation, the necessary sale expense deduction, see notes 13,53 supra, may also strengthen the traditional position of the Commissioner in opposing blockage. See note 36 supra and accompanying text. The regulations now provide for tax relief whenever a "necessary" sale to a dealer results in realization of less than the fair market value of the items sold. Treas. Reg. $\$ 20.2053-3$ (d) (2) (1958), as amended, T.D. 6826, 1965 INT. REv. BuL.L. No. 27, at 14. There is no exclusive categorization of items which qualify for this necessary sale treatment, and the sale of securities is arguably subsumed within the provision. Therefore, in a blockage situation where a "necessary" sale was actually made, deductive relief might be appropriate. An administrative expense equal to the amount that might have been realized but for the operation of the blockage element in lowering the price of the securities could be allowed. Under this approach, blockage would still be utilized to determine valuation where the securities are held by the estate or are sold in an "unnecessary" sale that does not qualify for the deduction, since the regulations accepting the blockage principle are unaffected by the recent amendments. However, this result appears anomalous since it permits valuation of securities in some situations based on a hypothetical sale in a secondary market, while an actual sale of other items of estate property to a dealer is not determinative of fair market value. If the Commissioner sees fit to revoke his blockage regulations, the amended regulations could be utilized by an estate where an actual necessary sale has occurred, and to justifiably deny the invocation of blockage where the securities are retained or sold in a situation where the sale is not "necessary."

However, by using the alternate valuation date, INT. REv. CoDE of 1954, § 2032, any executor who is willing to sell securities at a lower figure could avoid the blockage problem entirely by selling the stocks within one year after the decedent's death and taking that sale price for valuation.

${ }^{\circ}$ See note 5 supra. 
a definitive treatment, ${ }^{61}$ it may be desirable to leave these and future problems to the process of adjustment between the taxpayer and the Internal Revenue Service agents rather than to formulate additional "clarifications."

\footnotetext{
o1 " 'Value' is not a single purpose word. Men have all but driven themselves mad in an effort to definitize its meaning. The problem arises in its most perplexing form when ... property has not in fact been sold and an effort is made to ascertain what it would have fetched if it had been sold. . . [V]alue' almost always 'involves a guess, a prediction, a prophecy. ..." Andrews v. Commissioner, 135 F.2d 314, 317 (2d Cir.) (Frank, J.), cert. denied, 320 U.S. 748 (1943). Perhaps the most cogent observation is that "valuation is at best an opinion or guess ...." Lowndes \& Kramer, Federal ESTATE AND GifT TAXEs $\$ 18.16$, at 444 (2d ed. 1962).
} 